\title{
Evaluation of the sensory properties of a cosmetic formulation containing green coffee oil
}

\author{
Avaliação das propriedades sensoriais de uma formulação cosmética contendo óleo de café verde
}

\author{
Tais A. L. Wagemaker ${ }^{1 *}$, Catarina Rosado², Jirrah P. Andrade ${ }^{1}$, Ana Sofia Fernandes², Patricia Rijo ${ }^{2}$, \\ Patricia Maia Campos ${ }^{1}$ \& Luis M. Rodrigues ${ }^{2,3}$ \\ ${ }^{1}$ Universidade de São Paulo, Faculty of Pharmaceutical Sciences of Ribeirão Preto,Avenida do Café, s/n, \\ Ribeirão Preto, Brazil. \\ ${ }^{2}$ CBios - Research Center for Health Sciences \& Technologies, U. Lusófona, Campo Grande 376, \\ 1749-024 Lisboa, Portugal \\ ${ }^{3}$ Universidade de Lisboa, Pharmacological Sciences Department - School of Pharmacy, Lisboa, Portugal \\ Email: taisalw@uol.com.br
}

*Fundação de Amparo a Pesquisa do Estado de São Paulo (FAPESP)

\begin{abstract}
Green coffee oil (GCO) is a well-known ingredient with cosmetic properties such as: maintaining skin hydration, improving the sun protection factor and maintaining the skin barrier function. Thus, the aim of this study was to evaluate the impact of the addition of a considerable amount of GCO $(15 \%)$ on the sensory properties of a cosmetic formulation. The sensory panel consisted of nineteen volunteers aged between 19 and 43 years old. Sensory attributes were assessed on a $25 \mathrm{~cm} 2$ defined region on the internal side of the forearm. The volunteers were instructed to evaluate the sensory properties that they felt each formulation demonstrated, immediately after application and then after a further 5 minutes. The formulations had almost the same perceived effect among the volunteers. The majority of volunteers noted their skin as soft and moisturized after application of the formulations. However, the perception of an oily residue on the skin was the main effect of the formulation containing GCO. Thus, we can conclude that the total amount of GCO used, revealed interesting properties for use in dry skin or night creams, since it was able to leave an oily film on skin.
\end{abstract}

Keywords: Green coffee oil; cosmetics; sensory.

\begin{abstract}
Resumo
O óleo de café verde $(\mathrm{OCV})$ é um ingrediente bastante conhecido com propriedades cosméticas como: manter a hidratação da pele, melhorar o fator de proteção solar e manter a função barreira da pele. Assim, o objectivo deste estudo foi avaliar a influência da adição de uma quantidade considerável de $\mathrm{OCV}(15 \%)$ nas propriedades sensoriais de uma formulação cosmética. O painel sensorial consistiu de 19 voluntários com idades entre 19 e 43 anos. Os atributos sensoriais foram avaliadas em uma região definida de $25 \mathrm{~cm} 2$ na parte interna do antebraço. Os voluntários foram instruídos a avaliar as propriedades sensoriais que eles sentiam para cada formulação imediatamente e 5 minutos após a aplicação. As formulações mostraram quase a mesma percepção entre os voluntários. A maioria dos voluntários percebeu a pele suave e hidratada após a aplicação das formulações. No entanto, a percepção de um resíduo oleoso sobre a pele foi o principal efeito da formulação contendo OCV. Assim, podemos concluir que a quantidade total de OCV utilizado mostrou propriedades interessantes para aplicação em peles secas ou cremes noturnos, uma vez que foi capaz de deixar uma película oleosa sobre a pele.
\end{abstract}

Palavras-chave: óleo de café verde; cosméticos; sensorial. 


\section{Introduction}

The sensory properties of cosmetics are very important parameters to be considered in the development of these kind of products. Consumers are firstly attracted by advertising campaigns and packaging, however, if the cosmetic product does not provide good sensory properties like fast absorbency, spreadability and smoothness, the consumers will likely not buy it again. According to Fowler et al ${ }^{[1]}$, the efficacy of natural ingredients in skin products depends on the biological activity in vitro as well as in vivo, the type of vehicle used to deliver the product to the skin and the stability of this product once applied to the skin to exert the desired effect. However, none of these properties are as important as the cosmetic acceptability with respect to color, odor and texture.

GCO is extracted by mechanical pressure from unroasted beans of the Coffea arabica species. This oil has a yellow color and a characteristic odor that is welltolerated. It is very difficult to stabilize high amounts of GCO in cosmetic formulations, mainly due to its poor solubility. The intrinsic characteristics and the fast oxidation of this oil make its cosmetic development, as well as the sensory acceptability, challenging.

The sensory properties are usually evaluated by questionnaires. Each questionnaire is designed according to the panel of volunteers, the economic resources and the product to be tested.

According to Parente et $\mathrm{al}^{[2]}$, the application of external preference mapping on consumers' responses to a check-all-that-apply (CATA) questionnaire might be a reliable and interesting option when cosmetic companies face difficulties in using panels with trained assessors.

A CATA questionnaire consists of a list of words or phrases from which respondents should select all they consider appropriate to describe a product. Compared to other types of questionnaires, CATA questionnaires seem easier for consumers, less time-consuming and more natural to use ${ }^{[3]}$. According to Parente et al ${ }^{[4]}$, CATA questionnaires could provide information about how consumers perceive the products, what kind of emotions or values products or product elements arouse among users, and how all these construct their preference patterns. Pensé-Lhéritier et al ${ }^{[5]}$ also cited that the information obtained from CATA questionnaires is a direct result of the consumers' perception and may considerably help the marketing services in designing their sales strategy.

Stability, safety, efficacy and the sensory aspect are the most important parameters in developing a good cosmetic product. Our research group (NEATEC) has been studying three parameters (stability, safety and efficacy) of the cosmetic products containing green coffee oil. We were able to develop stable formulations

\section{Introdução}

As propriedades sensoriais dos produtos cosméticos são um dos parâmetros mais importantes para o desenvolvimento deste tipo de produtos. Os consumidores são primeiramente atraídos pelas campanhas de publicidade e pela embalagem, no entanto, se o produto cosmético não proporciona boas propriedades sensoriais, tais como: absorção rápida, espalhabilidade e suavidade, provavelmente os consumidores não irão comprá-lo novamente.

De acordo com Fowler et al ${ }^{[1]}$, a eficácia dos ingredientes naturais em produtos para a pele depende da actividade biológica in vitro, bem como in vivo, do tipo de veículo utilizado para penetração do produto na pele e da estabilidade desse produto quando aplicado na pele para que este exerça o efeito desejado. No entanto, nenhuma destas propriedades são tão importantes como a aceitabilidade cosmética com respeito ao odor, cor e textura.

O OCV é extraído por prensagem mecânica a partir de grãos torrados da espécie Coffea arabica. Este óleo apresenta odor característico e cor amarela que são bem tolerados. Estabilizar quantidades elevadas de OCV em formulações cosméticas é muito difícil, principalmente devido à sua dificuldade de solubilização. As características intrínsecas e a oxidação rápida do óleo fazem do desenvolvimento da formulação cosmética, bem como a sua aceitabilidade, um desafio. As propriedades sensoriais são normalmente avaliadas por meio de questionários. Cada questionário é montado de acordo com o painel de voluntários, os recursos económicos e o produto a ser testado.

De acordo com Parente et al ${ }^{[2]}$, a aplicação de um mapa de preferência externo sobre as respostas dos consumidores por meio de um questionário "CATA" pode ser uma opção viável e interessante quando as empresas de cosméticos enfrentarem dificuldades na utilização de painéis com avaliadores treinados . Um questionário "CATA" consiste de uma lista de palavras ou frases na qual os entrevistados devem selecionar tudo o que eles consideram apropriado para descrever um produto. Em comparação com outros tipos de questionários, o "CATA" parece ser mais fácil para o consumidor, menos demorado e é usado com mais naturalidade ${ }^{[3]}$. Segundo Parente et al ${ }^{[4]}$, o questionário "CATA" poderia fornecer informações sobre como os consumidores percebem os produtos, que tipo de emoções, valores ou elementos que os produtos despertam entre os usuários e, com isso possibiltar a construção de padrões de preferência. Pense-Lheritier et al ${ }^{[5]}$ também citaram que a informação obtida a partir de um questionário "CATA" é um resultado direto da percepção dos consumidores e pode ajudar consideravelmente os serviços de marketing na elaboração de sua estratégia de vendas. Estabilidade, segurança, eficácia e sensorial são os parâmetros mais importantes para desenvolver um bom produto cosmético. O nosso grupo de pesquisa 
containing high concentrations of GCO, and their efficacy and safety were demonstrated in previous works ${ }^{[6]}$.

According to Gilbert et al ${ }^{[7]}$ understanding the sensory properties of formulations will provide important information for product development in order to meet consumer satisfaction.

Thus, due to the importance of the sensory properties, the aim of this work was to study the volunteers' perception of cosmetic formulations containing high amounts of GCO.

\section{Material and Methods}

\section{Formulations}

The formulations studied were composed of deionized water, cetearyl alcohol + ceteareth-20 (Bernel), glycerin PA, methyldibromo glutaronitrile (Cosmotec), and BHT (vehicle-F0). This formulation was prepared using the mechanical agitator Heidolph (, RZR 2021, for 20 minutes, at 600rpm. The same conditions were employed to prepare the formulation containing $15 \%$ of GCO (Melscreen coffee, Chemyunion)-F15.

\section{Sensory evaluation}

The sensory panel consisted of 19 female volunteers from 19 to 43 years old. Sensory attributes were assessed according to well-defined procedures as described below. The procedures followed were in accordance with the ethical standards of the Lusófona University committee (A1/2004 March, 12th).

Volunteers were instructed to not use moisturizers, body lotions, soap or other occlusive cosmetic preparations on the tested area for $12 \mathrm{~h}$ prior to study.

All subjects remained in a room maintained at $25 \pm 1^{\circ} \mathrm{C}$ and $40-60 \%$ relative humidity for $15 \mathrm{~min}$ prior to evaluation.

The volunteers were asked to apply the product with one finger, performing the number of rubs needed to promote the absorption of $50 \mathrm{mg}$ of the formulations (vehicle and formulation containing $15 \%$ of GCO) on the delimited area $\left(25 \mathrm{~cm}^{2}\right)$ of the internal side of the forearm, i.e. 2 $\mathrm{mg} / \mathrm{cm}^{2}$. The volunteers evaluated the following attributes during application: oiliness, stickiness, smoothness, easy spreadability and speed of absorbance. Five minutes after application, they also evaluated the effects of each formulation on the skin using the following parameters: oily residue, soft skin, moisturized skin and white residue. The volunteers were instructed to mark only the parameters that they considered appropriate to describe a formulation in the questionnaire showed in Figure 1.
(NEATEC) está a estudar três parâmetros (estabilidade, segurança e eficácia) dos produtos cosméticos que contem óleo de café verde. Fomos capazes de desenvolver formulações estáveis contendo alta concentração de OCV e a sua eficácia e segurança foram demonstradas em trabalhos anteriores ${ }^{[6]}$.

De acordo com Gilbert et al ${ }^{[7]}$ a compreensão das propriedades sensoriais de formulações trará informações importantes para o desenvolvimento do produto, a fim de atender a satisfação do consumidor. Assim, devido à importância das propriedades sensoriais, o objetivo deste trabalho foi estudar a percepção dos voluntários de formulações cosméticas contendo grandes quantidades de OCV.

\section{Material e Métodos}

\section{Formulações}

As formulações estudadas foram compostas de água desionizada, álcool cetoestearílico + cetearete-20 (Bernel), glicerina PA, metildibromo glutaronitrila (Cosmotec), BHT (veículo - F0). Essa formulação foi preparada com agitador mecânico Heidolph ${ }^{\circledR}$, RZR 2021, durante 20 minutos a $600 \mathrm{rpm}$. As mesmas condições foram empregadas na preparação da formulação contendo $15 \%$ de OCV (Melscreen coffee, Chemyunion) - F15.

\section{Avaliação sensorial}

O painel sensorial foi realizada por 19 voluntários do sexo feminino 19-43 anos de idade. Os atributos sensoriais foram avaliadas de acordo com procedimentos bem definidos, tal como descrito abaixo. Os procedimentos a seguir estavam em concordância com os padrões éticos do Comiê da Universidade Lusófona (A1/2004, 12 de março).

As voluntárias foram instruídas a não usar hidratantes, loções corporais, sabão ou outras formulações cosméticas oclusivas na área do ensaio durante 12 horas antes do estudo.

Todos os indivíduos foram aclimatizados numa sala mantida a $25 \pm 1{ }^{\circ} \mathrm{C}$ e $40-60 \%$ de humidade relativa durante 15 minutos antes da avaliação.

Foi solicitado às voluntárias que aplicassem o produto com o dedo, a fazer o número de friç̧ões necessários para promover a absorção de $50 \mathrm{mg}$ das formulações (veículo ou formulação contendo $15 \%$ de OCV) na zona delimitada (25 $\mathrm{cm}^{2}$ ) do lado interior da antebraço, ou seja, $2 \mathrm{mg} / \mathrm{cm}^{2}$. As voluntárias avaliaram as formulações segundo os seguintes atributos durante a aplicação: oleosidade, pegajosidade, suavidade, fácil espalhabilidade e rápida absorção.

Cinco minutos após a aplicação, elas também avaliaram os efeitos de cada uma das formulações na pele pelos seguintes parâmetros: resíduo oleoso, pele macia, pele hidratada e resíduo branco. As voluntárias foram instruídas a marcar apenas os parâmetros que consideraram adequados para descrever a formulação que estavam a aplicar, como no modelo o questionário da Figura 1. 
NAME/ NOME:

\section{SENSORY EVALUATION / AVALIAÇÃO SENSORIAL}

Sensory characteristics during application

Caractetisticas sensoriais após aplicação

Sensory characteristics after 5 minutes application.

Effects on Skin.

Características sensoriais após 5 min. Efeitos na Pele

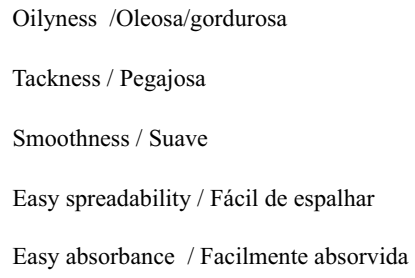

Figure 1 - Questionnaire model used in the present study.

Figura 1- Modelo de questionário usado no presente estudo.

\section{Results}

The perception of 19 volunteers was scored. The percentage of each sensory property attributed by the volunteers during the application is shown in Figure 2. Fig.2

\section{Resultados}

A percepção de 19 voluntárias foi avaliada. A porcentagem de cada propriedade sensorial atribuída durante a aplicação, pode ser vista na Figura 2.

Fig.2

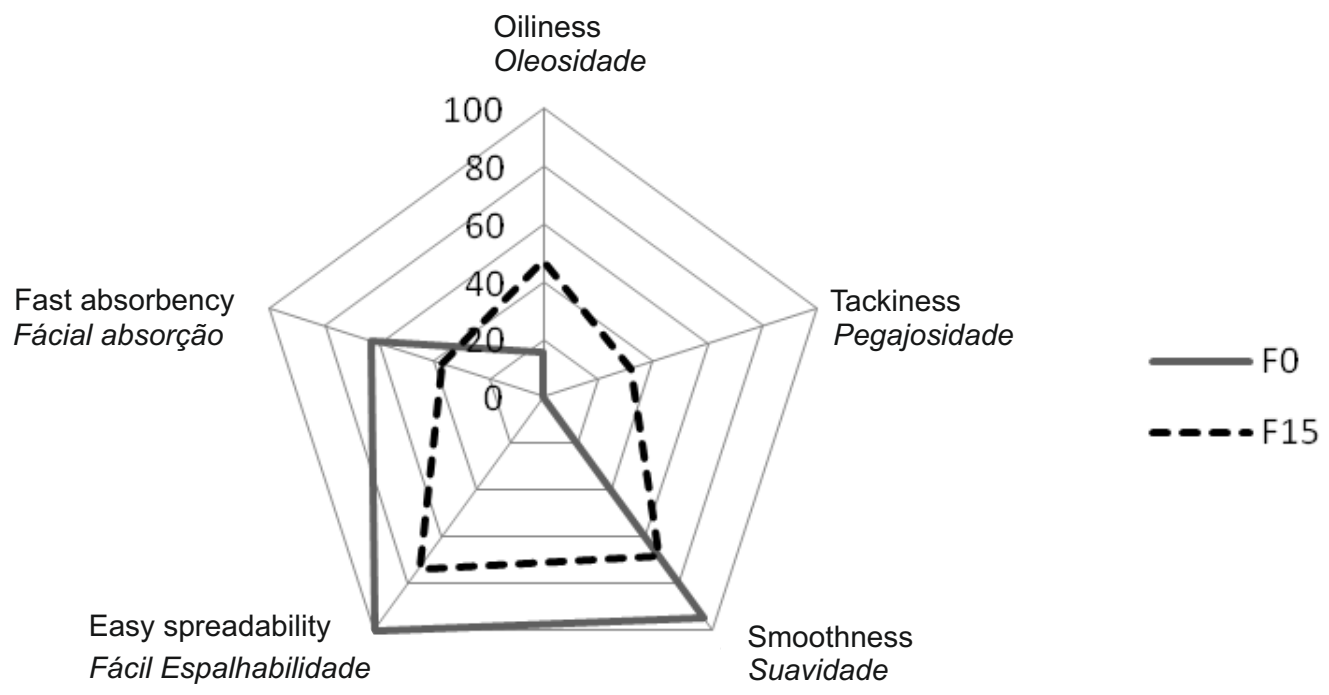

Figure 2 - Perception of volunteers during application.

Figura 2 - Percepção das voluntária durante a aplicação 
Almost all the volunteers marked the formulation without GCO as having smoothness and easy spreadability. Half of the volunteers noted the same formulation as having fast absorbency. The vehicle was also evaluated by the volunteers as possessing low oiliness and no stickiness. This perception indicates that the vehicle used was suitable.

However, when the vehicle is compared to the formulation containing GCO, the perception of undesirable properties like oiliness and stickiness is more evident. At the same time, the perception of smoothness, easy spreadability and fast absorbency decreases.

Five minutes after application, the same volunteers also registered their perception of the two formulations under study. This perception indicates the effects of the formulations on the skin.
Quase todas as voluntárias marcaram a formulação sem OCV como suave e fácil de espalhar. Metade das voluntárias registaram que a mesma formulação apresenta capacidade de absorção rápida. $\mathrm{O}$ veículo também foi avaliado como com pouca oleosidade e sem pegajosidade. Esta percepção das voluntárias indica que o veículo utilizado no estudo foi adequado. No entanto, quando o veículo foi comparado com a formulação contendo $\mathrm{OCV}$, a percepção de propriedades indesejáveis como oleosidade e pegajosidade foram maiores. Ao mesmo tempo, a percepção de fácil espalhabilidade, suavidade e rápida absorção foram menores.

Após 5 minutos de aplicação, as mesmas voluntárias também marcaram sua percepção sobre as duas formulações em estudo. Esta percepção indica os efeitos das formulações na pele.

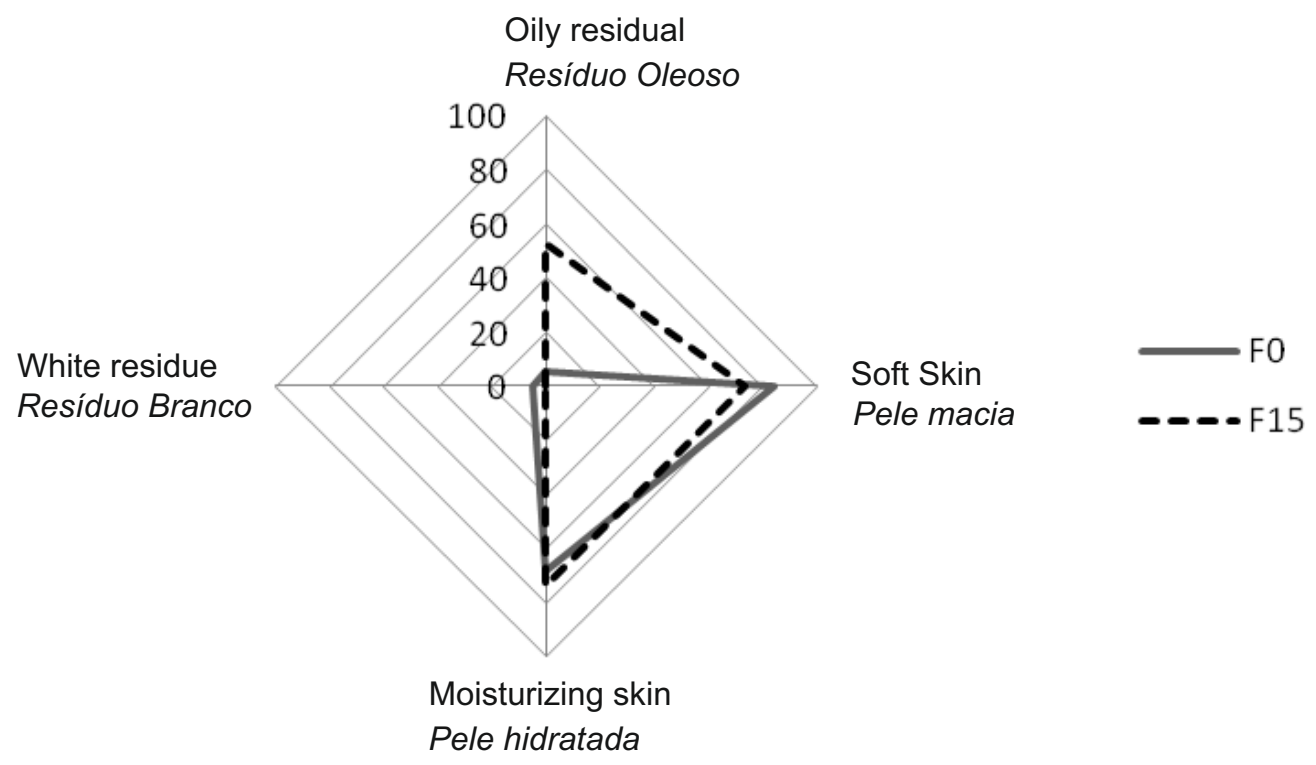

Figure 3 - Perception of volunteers after five minutes application.

Figura 3 - Percepção das voluntárias após 5 minutos de aplicação.

The formulations had almost the same perceived effect among the volunteers (Figure 3). A small percentage of volunteers noted a white residue for the formulation without GCO only. The majority of volunteers noted their skin as soft and moisturized after application of the formulations. The oily residue after F15 application was noted in half of the volunteers.
As formulações mostraram quase as mesmas propriedades sensoriais de acordo com a percepção das voluntárias (Figura 3). Uma pequena percentagem de voluntárias registou um resíduo branco apenas para a formulação sem OCV. A maioria das voluntárias notou a pele suave e hidratada após a aplicação das formulações. A sensação de resíduo oleoso após aplicação de F15 foi notado para metade das voluntárias. 


\section{Discussion}

High concentrations of vegetable oils added to skin care formulations are valuable in skin protection, mainly because they prevent transepidermal water loss and dermatitis. However, it is necessary to evaluate the sensory properties of formulations, since they can strongly influence the customer's choice.

According to Savary et al ${ }^{[8]}$, spreading of a cosmetic cream is a determinant textural attribute that governs the performances of the product during its application on the skin. Parente et al ${ }^{[9]}$ states that both difficulty of spreading and stickiness are related to physicochemical properties such as viscosity, which measures the resistance to flow. All the formulations showed easy spreadabilty for the majority of volunteers.

In previous work, Wagemaker et al ${ }^{[10]}$ studied the rheological behavior of formulations with or without GCO, in five concentrations - 0, 2.5, 5, 10 and 15\%. The formulation containing $15 \%$ of GCO (F15) showed the highest viscosity $( \pm 3000 \mathrm{cP})$ and flow index (0.45) while the other formulations showed shorter viscosity $( \pm 1500 \mathrm{cP})$ and flow index $(0.22$ to 0.29 ).

Wagemaker et al ${ }^{[6]}$ evaluated the immediate efficacy of the formulations containing high amounts of GCO in the improvement of skin conditions. They found that formulations containing high amounts of GCO were able to reduce the transepidermal water loss and significantly increase stratum corneum water content. However, according to Savary et al ${ }^{[8]}$, high viscosity and flow index of F15 indicates difficulty in spreading. In this work, we decided to evaluate only one formulation containing a high amount of GCO and tried to confirm that formulations containing high amounts of vegetable oils could promote improvement in skin conditions as well as pleasant sensory properties.

Despite the high viscosity and flow index of F15, we observed that this formulation was considered to be easily spreadable for almost $80 \%$ of the volunteers which indicates that all formulations were approved with regard to this sensory property.

During product development, cosmetic companies need information about how much consumers like a product, which sensory characteristics they expect to find, as well as their emotional associations. This information might enable them to adequately meet consumer expectations and assure the products' success on the market ${ }^{[2]}$.

More than $50 \%$ of the volunteers that participated in this study considered the formulation containing GCO as having smoothness. However, almost 50\% noted oiliness during the application. Five minutes after application, the formulation containing GCO gave the

\section{Discussão}

A adição de altas concentrações de óleos vegetais em formulações cosméticas para cuidado da pele é de grande valor na proteção da pele, principalmente para prevenir a perda transepidérmica de água e dermatites. No entanto, é preciso avaliar o sensorial da formulação, uma vez que, este pode influenciar o consumidor na escolha do produto.

De acordo com Savary et al ${ }^{[8]}$, a espalhabilidade de um creme cosmético é um atributo estrutural determinante que governa o desempenho do produto durante a sua aplicação sobre a pele. Parente et al ${ }^{[9]}$, referem que a dificuldade de espalhar e a aderência estão relacionadas com propriedades físico-químicas tais como a viscosidade, o qual mede a resistência ao fluxo. Todas as formulações mostraram fácil espalhabilidade para a maior parte dos voluntários.

Em trabalhos anteriores, Wagemaker et al (submetido à publicação) estudaram o comportamento reológico das formulações contendo ou não $\mathrm{OCV}$ nas seguintes concentrações 2,$5 ; 5 ; 10$ e 15\%. A formulação contendo $15 \%$ de OCV (F15) apresentou a maior viscosidade ( \pm $3000 \mathrm{cP})$ e índice de fluxo $(0,45)$ enquanto que as outras formulações apresentaram menor viscosidade $( \pm 1500 \mathrm{cP}) \mathrm{e}$ índice de fluxo $(0,22-0,29)$.

Wagemaker et al (6) avaliaram a eficácia imediata das formulações que contêm quantidades elevadas de OCV na melhoria das condições da pele. Eles encontraram que as formulações que contêm quantidades elevadas de OCV foram capazes de reduzir a perda transepidérmica de água e aumentar significativamente o conteúdo aquoso do estrato córneo. No entanto, de acordo com Savary et al ${ }^{[8]}$, a elevada viscosidade e índice de fluxo de F15 indicam sua dificuldade em se espalhar essa formulação.

Neste trabalho, nós decidimos avaliar apenas uma formulação contendo alta concentração de OCV para tentar confirmar que as formulações que contêm quantidades elevadas de óleos vegetais podem apresentar melhoria das condições da pele e também agradáveis propriedades sensoriais.

Observou-se, apesar da viscosidade e índice de fluxos elevados de F15, que esta formulação foi considerada como fácil de espalhar por quase $80 \%$ das voluntárias o que indica que todas as formulações foram aprovados para esta propriedade sensorial.

Durante o desenvolvimento do produto, as empresas de cosméticos precisam de informações sobre o quanto os consumidores gostam do produto, quais as características sensoriais que eles esperam encontrar, bem como as suas associações emocionais. Estas informações podem permitirlhes atender adequadamente as expectativas dos consumidores e assegurar o sucesso dos produtos no mercado ${ }^{[2]}$.

Mais de $50 \%$ das voluntárias que participaram neste estudo consideraram a formulação contendo OCV como suave. No entanto, quase $50 \%$ notaram oleosidade durante a aplicação. Após 5 minutos da aplicação, a formulação 
sensation of oil on the skin for half of the volunteers. This oily residue is common for many emollients due to the film that cosmetic emulsions leave on the skin.

According to Parente et $\mathrm{al}^{[11]}$, the film has a protective effect on skin and the emollients that produce it, as was verified for GCO, can be used in products for night skin care, dry skin and in cold countries. Futhermore, Kaur and Saraf ${ }^{[12]}$ states that oily vehicles are more effective for producing a uniform and long-lasting film of sunscreen on the skin, and their emollient properties protect the skin against the drying effects of exposure to wind and sun.

In addition, GCO is a complex mixture of triglycerides containing high amounts of linoleic and palmitic acid

[13]. A previous work states that GCO is able to regenerate and protect the skin barrier function ${ }^{[6]}$.

Regarding the methodological part of this study, the CATA questionnaire could provide an interesting insight into consumers' perception of formulations containing high concentration of GCO. We recommend that more studies be carried out with formulations containing high amounts of vegetable oils.

Finally, the results of this work contribute to the knowledge of consumers' perception regarding formulations containing high concentration of seed oils, mainly GCO. The use of high concentration of GCO is indicated in night skin care and in dry skin products, as well as in products for consumers living in countries with a cold climate, because it can form an oily film that has a protective effect on skin.

\section{Conclusions}

Under the experimental conditions of this work, we can conclude that GCO in high concentrations influenced the sensory properties of the studied formulation, above all the perception of an oily film on the skin. However, this film is important to protect and keep the skin hydrated.

\section{Acknowledgement}

The authors thank FAPESP for granting financial support for this study.

\section{Conflict of Interest}

The authors declare that there is no financial or personal relationship that can be understood as representing a potential conflict of interest. contendo OCV mostrou sensorial de óleo sobre a pele para a metade dos voluntários. Este resíduo oleoso é comum para muitos emolientes, devido ao filme que deixam na pele.

De acordo com Parente et al ${ }^{[10]}$, a película forma um efeito protector sobre a pele e os emolientes que produzem esta película oleosa de protecção sobre a pele, tal como foi verificado para OCV, podem ser utilizados em produtos para o cuidado noturno da pele, pele seca e em países de clima frio. Além disso, Kaur e Saraf ${ }^{[12]}$ afirmam que veículos oleosos são mais efetivos para produção de uma película uniforme e de longa duração do filtro solar sobre a pele, e suas propriedades emolientes protegem a pele contra os efeitos da exposição ao vento e ao sol.

Além disso, o OCV é uma complexa mistura de triglicerídeos que contêm grandes quantidades de ácido linoleico e ácido palmítico ${ }^{[13]}$. Estudos anteriores mostraram que OCV é capaz de regenerar e proteger a função barreira da pele ${ }^{[6]}$.

Quanto à parte metodológica deste estudo, o questionário CATA poderia fornecer uma visão interessante sobre a percepção do consumidor de formulações contendo alta concentração de OCV. Nesse sentido, nós recomendamos mais estudos com formulações contendo grandes quantidades de óleos vegetais.

Por fim, os resultados deste trabalho contribuem para o conhecimento da percepção dos consumidores em relação a formulações contendo alta concentração de óleos vegetais, especificamente o OCV. O uso de altas concentrações de OCV é indicado em cuidados noturnos da pele e em produtos para a pele seca, bem como em produtos para consumidores que vivem em países com clima frio devido a esta poder formar um filme oleoso protetor sobre a pele.

\section{Conclusão}

Nas condições experimentais deste trabalho podemos concluir que em altas concentrações o óleo de café influenciou o sensorial da formulação estudada, principalmente em relação a sensação de um filme oleoso na pele. No entanto, a formação deste filme é importante para a proteção e manutenção da hidratação da pele.

\section{Agradecimentos}

Os autores agradecem o apoio financeiro da FAPESP.

\section{Conflitos de interesse}

Os autores declaram não existir qualquer relação de natureza financeira ou pessoal que possa ser entendida ou representar um potencial conflito de interesses. 


\section{References / Referências}

[[1]. Fowler JF, Woolery-Lloyd H, Waldorf H, Saini R. Innovations in natural ingredients and their use in skin care. J Drugs Dermat 2010; 9: 72-81.

[2]. Parente ME, Manzoni AV, Ares G. External preference mapping of commercial antiaging creams based on consumers' responses to check-all-that-apply question. J Sensory Studies 2011; 26: 158-166.

[3]. Adams J, Williams A, Lancaster B, Foley M. Advantages and uses of check-all-that-apply response compared to traditional scaling of attributes for salt snacks. In 7th Pangborn Sensory Science Symposium. Minneapolis, USA, 2007.

[4]. Parente ME, Ares G, Manzoni AV. Application of two consumer profiling techniques to cosmetic emulsions. J Sensory Studies 2010; 25: 685-705.

[5]. Pensé-Lhéritier AM, Koehl L, Lavarde M, Gagnaire $\mathrm{S}$, Vie K. Contribution of the sensorial evaluation of velvet fabric in cosmetic emulsions to the sensorial universe. J Sensory Studies 2012; 27: 365-374
[6]. Wagemaker TAL, Demets MBA, Benevenuto CG, D'Almeida D, Baby A, Frade MAC, Maia Campos PMBG. Efeitos fotoprotetores do óleo de café em formulações cosméticas. In $26^{\circ}$ Congresso Brasileiro de Cosmetologia, São Paulo, Brazil, 2012.

[7]. Gilbert L, Picard C, Savary G, Grisel M. Impact of polymers on texture properties of cosmetic emulsions: a methodological approach. J Sensory Studies 2012; 27 : 392-402.

[8]. Savary G, Grisel M, Picard C. Impact of emollient on the spreading properties of cosmetic products: a combined of sensory and instrumental characterization. Colloids Surfaces B: Biointerfaces 2013; 102: 371-378.

[9]. Parente ME, Gámbaro A, Solana G. study of sensory properties of emollients used in cosmetics and their correlation with physicochemical properties. J Cosmet Sci 2005; 56: 175-182.

[10]. Wagemaker TAL, Siva SAM, Leonardi GR, Baby $\mathrm{AR}$, Frade MAC, Maia Campos PMBG. Influence of green coffee oil in physical stability and photoprotective effects of skin care formulations: a multivariate analysis. Submitted for publication.

[11]. Parente ME, Gámbaro A, Ares G. Sensory characterization of emollients. J Sensory Studies 2008; 23: $149-161$

[12]. Kaur CD, Saraf S. In vitro Sun protection factor determination of herbal oils used in cosmetics. Pharmacognosy Res 2010; 2 (1): 22-25

[13] Wagemaker TAL, Leonardi GR, Maia Campos PMBG. Aplicação do óleo de café em formulações fotoproteoras. In XX Congresso Íbero Americano de Químicos Cosméticos, Isla Margarita, Venezuela, 2011. 